\title{
The Efficacies of Banana Stem Extract as A Candidate of Coccidiostat Against Rabbit Eimeria Stiedai Oocysts: An in Vitro Analysis
}

\author{
Diana Indrasanti ${ }^{1}{ }^{1}$, Mohandas Indradji $^{1}$, Sri Hastuti $^{1}$, Hevi Wihadmadyatami ${ }^{2}$ and Ismoyowati $^{3}$ \\ ${ }^{1}$ Department of Animal Health, Faculty of Animal Science, University of Jenderal Soedirman, \\ Jl. Dr. Suparno 60, Purwokerto 53123, Indonesia \\ 2Department of Anatomy, Faculty of Veterinary Medicine, University of Gadjah Mada, \\ Jl. Fauna 2 Yogyakarta 55281 Indonesia \\ ${ }^{3}$ Department of Poultry Science, Faculty of Animal Science, University of Jenderal Soedirman, \\ Jl. Dr. Suparno 60, Purwokerto 53123, Indonesia \\ *Corresponding author email: dianaindrasanti@gmail.com
}

\begin{abstract}
The objective of this research was to investigate the ability of banana stem (Musa paradisiaca) to inhibit sporulation of Eimeria stiedai oocysts derived from rabbit by in vitro analysis. Analyze the active substance proximate analysis and active substances in this research were performed too. Banana stem extract were used in this experiment and sulfaquinoxalline $\left(\mathrm{Coxy}^{\circledR}\right)$ was run as a control. The Eimeria stiedai oocysts were incubated prior the presence of different concentration from banana stem extract $0 \%, 1 \%, 2 \%, 4 \%, 8 \%$ for 1,2 and 3 days at $26^{\circ} \mathrm{C}$. In addition, Factorial patterned Completely Randomized Design (CRD) with five replicates was applied on the experiment. Result analysis was performed by using Analysis of Variance and following by Honestly Significant Difference (HSD) post hoc test. Here, we identified that banana stem extract contain different type of active substance such as tannin, saponin, and alkaloid. Banana stem extract significantly affected the oocysts sporulation included the amount of sporulated oocysts $(P<0.01)$, unsporulated oocysts $(P<0.01)$, and transformed oocysts $(P<0.01)$. In conclusion banana stem could inhibit the development of Eimeria stiedai oocysts on in vitro experiment. HSD test showed that the optimum potential efficacy of banana stem to inhibit sporulation was at $4 \%$ and $8 \%$ concentration during three days incubation.
\end{abstract}

Key words: Eimeria stiedai, rabbit coccidiosis, banana stem

Abstrak. Penelitian ini bertujuan untuk mengetahui kemampuan batang pisang (Musa paradisiaca) untuk menghambat kemampuan sporulasi ookista Eimeria stiedai kelinci melalui analisis secara in vitro. Pada penelitian ini juga dilakukan analisis proximat dan kandungan fitokimia ekstrak batang pisang. Ekstrak batang pisang digunakan pada penelitian ini dan kontrol sulfaquinoxalline $\left(\operatorname{Coxy}^{\circledast}\right)$. Ookista Eimeria stiedai kelinci diinkubasi dengan konsentrasi yang berbeda yaitu $0 \%, 1 \%, 2 \%, 4 \%, 8 \%$ selama 1,2 dan 3 hari pada suhu $26^{\circ} \mathrm{C}$ bersama ookista Eimeria stiedai selama 1,2 dan 3 hari. Rancangan penelitian yang digunakan adalah Rancangan Acak Lengkap (RAL) pola faktorial, dengan pengulangan sebanyak 5 kali. Hasil analisis ditentukan dengan analisis variansi dilanjutkan uji lanjut Beda Nyata Jujur (BNJ). Ekstrak batang pisang mengandung beberapa zat aktif yaitu tanin, saponin dan alkaloid. Ekstrak batang pisang berpengaruh signifikan terhadap kemampuan sporulasi ookista yang meliputi jumlah ookista bersporulasi $(P<0,01)$, ookista yang tidak bersporulasi $(P<0,01)$ dan ookista yang mengalami perubahan bentuk $(P<0,01)$. Kesimpulan dalam penelitian ini bahwa batang pisang mampu menghambat perkembangan koksidia Eimeria stiedai secara in vitro. Uji BNJ menunjukkan potensi efektifitas terbaik ekstrak batang pisang diperoleh secara in vitro terhadap $E$. stiedai pada konsentrasi $4 \%$ dan $8 \%$ dengan lama inkubasi 3 hari.

Kata kunci: Eimeria stiedai, koksidiosis kelinci, batang pisang

\section{Introduction}

Rabbit coccidiosis is a disease caused by infection of protozoa Eimeria sp. This disease is very prevalent and chronic in young rabbits, whereas adult rabbits only act as a carrier. Two type of coccidiosis in rabbit already describe there are hepar coccidiosis caused by Eimeria stiedai and intestinal coccidiosis caused by Eimeria magna, Eimeria perforans, Eimeria 
media, Eimeria irresidua, Eimeria piriformis, Eimeria caecicola, Eimeria intestinalis, Eimeria nagpurensis, Eimeria matsubayashii, Eimeria exigua, Eimeria vejdovskyi, Eimeria flaverscens, Eimeria roobroucki, Eimeria agnosta and Eimeria oryctolagi (Pakandl, 2009). Following the infection of Eimeria $s p$ anorexia, abdominal swelling, diarrhea and weight loss usually occurs, but the specific clinical sign for E. stiedai infection are liver swelling, bile duct widened, jaundice and persistence of white nodules in various sizes on the liver surface which containing viscous fluid and oocysts (Al-Rukibat et al., 2001; Al-Mathal, 2008).

For the coccidiosis treatment generally coccidiostat, e.g. ionophores, amprolium, sulphonamides, ethopabate, clopidol and quinolones are applied (Kant et al., 2013). However, the regular use may cause parasite resistance, additionally medicine residue in meat also need to be in attention concerning to consumer health disorder. Live vaccines are another method for controlling coccidiosis in domestic poultry (Pakandl, 2009; Price, 2012; Chapman and Jeffers, 2014). Nevertheless, the use of this vaccine has not been fully accepted, partly because of economic reasons, the side effects during early treatment and this vaccine only give temporary protective immunity (Williams, 2002), moreover the use of live vaccines should be followed by maintenance and good health in order to enhance the vaccine function optimally (Yang et al., 2012). Recently the awareness regarding to antibiotic control as a feed additive or AGP (Antibiotic Growth Promotor) have been announced by WHO, OIE and Ministry of Agriculture Indonesia as a global issues.

In a few years, research on medicinal plant has been widely increasing since active substances in some plants are found as potential coccidiostat to overcome the residues and resistance problem (Yellita et al., 2011). Previous researches reported that herbal plants such as Pinus radiata (Molan et al., 2009), Andrographis paniculata (Yon and Noh, 2001),
Artemisia annua (Drăgan et al., 2014; Zaman et al., 2015), Eupatorium adenophorum (Yellita et al., 2011), and Carica papaya (Al-Fifi, 2007) give significant result to control coccidiosis when used as a coccidiostat in chicken. The development of traditional medicine offers wide opportunity for tropical countries which enriched with natural resources to overcome problems which may occurs because of administrated coccidiostat antibiotic in poultry and rabbit feed.

Banana is one of the popular fruits in the world and has antibacterial content (Wall, 2006), in addition, Matekaire et al found that the roots of banana plants can also be used as coccidiostat (Matekaire et al., 2005). Unfortunately, in Indonesia most of the waste from banana stems is not fully utilized, and there is also little information about the capability banana stem to apply as antibacterial and coccidiostat. Accordingly, the purpose of this study was to determine the effectiveness of banana stem extract against Eimeria stiedai oocysts to control rabbit coccidosis on in vitro analysis.

\section{Materials and Method}

\section{Plant material preparation}

The center part of banana stem (Musa paradisiaca) was collected and machine-dried (Fischer Scientific, Massachusetts, United States) at $55^{\circ} \mathrm{C}$ for 4 days, then ground to powder (Islam et al., 2008). Plant extraction followed maceration method using $70 \%$ ethanol. One hundred gram of plant powder was soaked in 1 liter of $70 \%$ ethanol for $24 \mathrm{~h}$ followed by filtration. The residue was filtrated with $500 \mathrm{~g}$ solvent for $24 \mathrm{~h}$. filtrate was evaporated in rotary evaporator (Stuart, Staffordshire, UK) (Iqbal et al., 2013). The extract was steamed in $45-55^{\circ} \mathrm{C}$ water bath (Fischer Scientific, Massachusetts, United States), then measured based on the concentration amount of the extract which will used for the analysis (\% b/v) $0 \%, 1 \%, 2 \%, 4 \%$ 
and $5 \%$. Each group of extract was added with $0.5 \% \mathrm{Na}$ CMC. $5 \mathrm{~g} / \mathrm{L}_{\text {sulfaquinoxalline (Coxy }}^{\circ}$ Medion, Bandung, Indonesia) was performed as positive control. Phytochemical analysis banana stem qualitatively and quantitatively was conducted by Indonesian Spice and Medicinal Crops Research Institute, Bogor, Indonesia. Proximate analysis banana stem was made in Laboratory of Animal Feed Science, Jenderal Soedirman University, Indonesia.

\section{Cultivation of Eimeria stiedai oocysts}

Eimeria stiedai isolate was multiplied in vivo by infecting $10^{3}$ Eimeria stiedai to 5 free-coccidian Rex breed rabbits (2 years old, 700 gram). Rabbit faeces was collected and examined under floatation test, and the oocysts was counted using Mc. Master method, following by adding $2 \%$ potassium dichromate $\left(\mathrm{K}_{2} \mathrm{Cr}_{2} \mathrm{O}_{7}\right)$, oocysts was cleaned thoroughly at least 3 times before usage (Coudert et al., 1995). Observations of amount oocysts sporulation and not sporulation were done by using light microscope (Leica, Wetzlar, Germany) with the $10 \times$ and $40 \times$ magnification on first, second and third days incubation.

\section{Oocysts incubation in plant extract}

Approximately 10 oocysts or 500 oocysts per gram faeces (opg) were used. The mixture which is contain oocysts, $0.5 \% \mathrm{Na} \mathrm{CMC}$ and banana stem extract with different concentration $0 \%(\mathrm{AO}), 1 \%(\mathrm{~A} 1), 2 \%(\mathrm{~A} 2), 4 \%$ (A3) dan $8 \%$ (A4) and sulfaquinoxalline (A5) were incubated for 1, 2 and 3 days in incubator (Fischer Scientific Massachusetts, United States) at $26^{\circ} \mathrm{C}$. The observation parameters were oocysts sporulation included the sporulated oocysts, unsporulated oocysts and transformed oocysts from 1, 2 and 3-day incubation. Experiment was conducted in factorial patterned Completely Randomized Design (CRD) with 5 replicates. Factor A was concentration (\%) and factor $B$ was incubation period (day). Data were analysis by using
Analysis of Variance followed by Honestly Significant Difference (HSD) Test (Steel and Torrie, 1980). Research was performed in the Livestock Health Laboratory, Research Laboratory and Experimental Farm, University of Jenderal Soedirman, Central Java, Purwokerto, Indonesia.

\section{Results and Discussion}

Banana easily grows in tropical and subtropical region such as Indonesia, Malaysia, Australia and Asian countries. This plant is the source of food, beverages, fermentable sugar, medicines, flavorings, cooked foods, silage, fragrance, rope, cordage, garland, clothing, and numerous ceremonial uses (Nelson et al., 2006). Banana plant only bears fruit once during their life, which is why after harvesting time there are so many stems are discarded and not optimally utilized. In this research, we try to used banana stem as coccidiostat and we are postulated that banana stem extract may prevent oocysts development as well as like in banana root application.

In this study we performed an analysis to characterize the ingredient from banana stem extract. Based on proximate and phytochemistry analysis (Table 1 ) banana stem extract harbor several substance including water, ash, crude fat, crude protein, non-fat extraction (NFE) and carbohydrate. Based on our proximate analysis result (Table 1 ), the extract of banana stem contained $16.93 \%$ higher mineral in compare to the other herbal plant, the highest content was carbohydrate (75.18\%) and the crude fiber (12.65\%). Qualitative phytochemical analysis demonstrated that banana stem contain several secondary metabolite such as saponin, alkaloid, phenolic, tannin, flavonoid and triterpenoid. Furthermore qualitative phytochemical test describe the presence of tannin $(0.67 \%)$, flavonoid $(0.06 \%)$ and saponin $(0.54 \%)$. 
Table 1. Proximate analysis results of banana (Musa paradisiaca) stem powder

\begin{tabular}{clc}
\hline No & \multicolumn{1}{c}{ Parameter } & Content (\%) \\
\hline 1 & Water & 11.40 \\
2 & Ash & 16.93 \\
3 & Crude fat & 1.97 \\
4 & Crude fiber & 12.65 \\
5 & Crude protein & 5.92 \\
6 & NFE & 62.53 \\
7 & Carbohydrat & 75.18 \\
\hline
\end{tabular}

Banana plants are known to contain mineral compounds, phenol compounds, and compounds of simple sugars; whereas in starch compounds it is used as an energy source. Giving part of banana plant is usually mixed with other ingredients as a source of protein or energy (Wina, 2001). In addition, flour derived from banana stems also contains macro and micro minerals in quite high concentration (Wina et al., 2000). In accordance to our finding, the advantages of some macro and micro mineral e.g. tannin and alkaloid in Andrographis paniculata was related to the parasite calcium canal. Alkaloid may block the calcium canal thus induce calcium secretion disorder and finally promote the damage of sporozoites and prevent sporozoites invasion. Eventually it may decrease the amount of parasite describe by decreasing oocysts fecal excretion (Yellita et al., 2011; Presetyo et al., 2010). Moreover, saponin and quinone have a function as antibacterial (Yellita et al., 2011). Based on this explanation we can postulated that the existence of secondary metabolite as active substance in banana stem extract is important for the antiprotozoal activities especially against coccidian and antibacterial. Based on microscopic observation during the incubation time 1, 2, and 3 days, when the oocysts were incubated together with different concentrations of banana stem extract, the sporulated and unsporulated microscope still presence, additionally transformation oocysts also have been found. Oocysts were oval, encapsulated and thin-walled (Al Mathal, 2008). Oocysts incubation caused the sporulated oocysts where oocysts contained 4 sporocysts and 2 sporozoites (Figure 1).

Sporulation occurred in Eimeria stiedai upon $57 \mathrm{~h}$ incubation at $26^{\circ} \mathrm{C}$. Table 2 presents that the highest average of unsporulated oocyst at $8 \%$ concentrate in 1-day incubation. The highest amount of sporulated oocysts was at $0 \%$ concentrate in 3-day incubation, and the highest amount of transforming oocysts was at $4 \%$ concentration in 3-day incubation. The effect of banana stem extract on oocysts sporulation was increasing from day 1 , day 2 and day 3 at $0 \%, 1 \%$ and $2 \%$ concentration. While at $4 \%, 8 \%$ concentration and $\mathrm{Coxy}^{\circledR}$, the effect increased on day 1 and day 2 but decreased on day 3 . Analysis of variance result of the interaction between banana stem extract with different concentration and incubation period significantly affected the amount of unsporulated oocysts $(P<0.01)$, sporulated oocysts $(P<0.01)$ and transformed oocysts $(P<0.01)$. Result of Honestly Significant Difference (HSD) test showed that the highest content of unsporulated oocysts was obtained at $4 \%$ concentration in 1 day incubation, while the highest sporulated oocysts was at $0 \%$ concentration in 3 day incubation and the highest transformed oocysts was at $4 \%$ concentration in 3 day incubation (Figure 2). No transformed oocysts were found in negative control treatment or $0 \%$ concentration.

Banana stem extract had more significant effect on sporulated oocysts in which optimum sporulation occurred on day 2 , while on day 3 the sporulated oocysts decreased, but the transformed oocysts increased. Furthermore, during the incubation on the supplementing $4 \%$ and $8 \%$ banana stem extract had more significant effect to inhibit the development of sporulated oocysts than $\mathrm{Coxy}^{\circledR}$. When the active substance in banana stem extract could penetrate oocysts wall, it will interrupt sporocysts and sporozoites wall, causing the transformed or damaged oocysts, finally resulted the lysis of oocysts wall and eventually the mortified Eimeria stiedai oocysts cell. This 
evidence was in line with Molan et al. (2009) where tannin in pine skin could penetrate oocysts cell, and induce rupture of sporozoites and sporocysts. However, it was unobserved whether the transformed oocysts were infectious.

Banana stem could inhibit coccidia development as it was in banana root. Banana plant contained many active substances (secondary metabolites), which can act as an antibacterial against Staphylococcus aureus and Escherichia coli. The results showed that crude extracts have significant antibacterial activity against S. aureus and E. coli (Ningsih et al, 2013). The lectin contains in banana plant stimulates skin cell growth as it correlates with phagocytosis, complement activity, leucocyte extravacation, innate immunity and lymphocyte activation (lordanche, 2015).
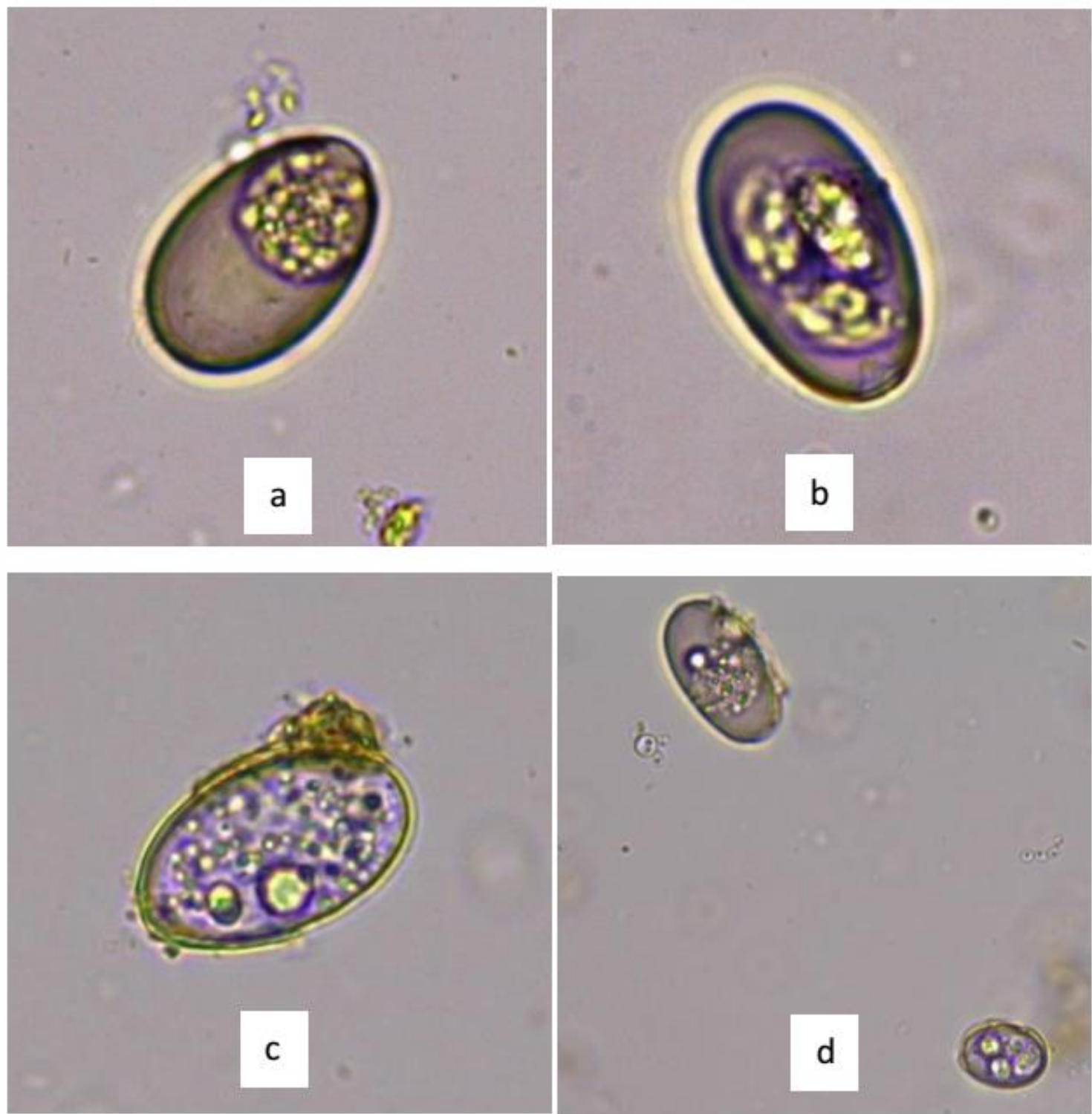

Figure 1. Macroscopic appearance of the morphology of oocysts incubated with banana stem extract in different concentration. Oocysts morphology incubated banana stem extract. a. Unsporulated oocyst, b. Sporulated oocyst, c and d. Transformed oocysts 


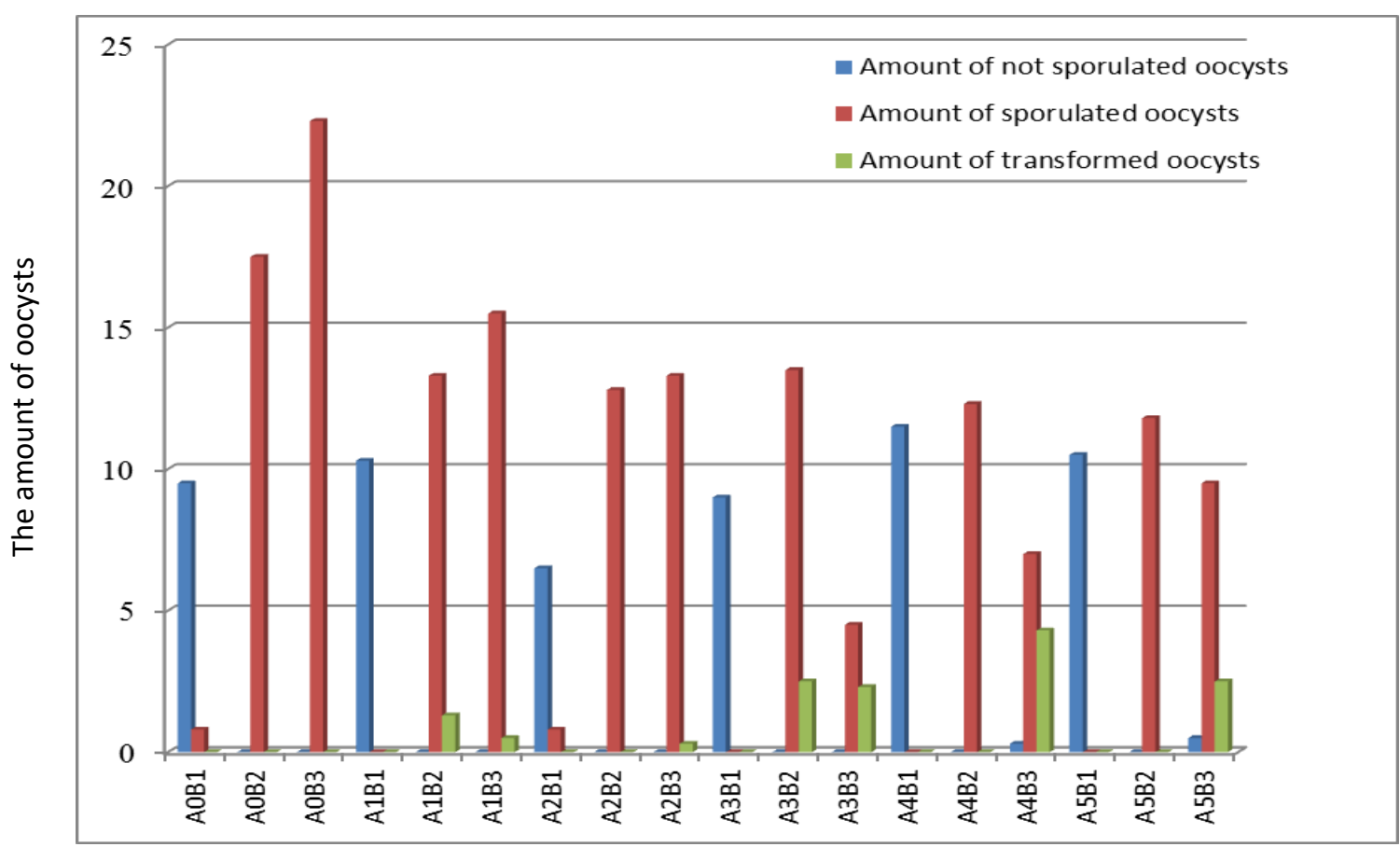

Treatment combinations

Figure 2. Comparison of total average of sporulated oocysts, unsporulated oocyts and transformed oocysts with different concentration of banana stem extract with 1,2 and 3 day incubation. $A(0,1,2,3,4,5)=$ banana stem extract concentration $\left(0 \%, 1 \%, 2 \%, 4 \%, 8 \%\right.$ and $\left.\operatorname{Coxy}^{\circledR}\right) ; B(1,2,3)=$ incubation period $(1,2$ and 3 days $)$

Table 2. Average oocysts of Eimeria stiedai supplemented with banana (Musa paradisiaca) stem extract in different concentration during 1, 2 and 3-day incubation

\begin{tabular}{ccccc}
\hline $\begin{array}{c}\text { Treatment } \\
\text { combination }\end{array}$ & $\begin{array}{c}\text { Unsporulated } \\
\text { oocysts }\end{array}$ & $\begin{array}{c}\text { Sporulated } \\
\text { oocysts }\end{array}$ & $\begin{array}{c}\text { Transformed } \\
\text { oocysts }\end{array}$ & $\begin{array}{c}\text { Effect on oocysts } \\
\text { development (\%) }\end{array}$ \\
\hline A0B1 & $9.5 \pm 1.3^{\mathrm{ab}}$ & $0.8 \pm 1.5^{\mathrm{f}}$ & $0.0 \pm 0.0^{\mathrm{b}}$ & $7.77 \%$ \\
A0B2 & $0.0 \pm 0.0^{\mathrm{c}}$ & $17.5 \pm 2.1^{\mathrm{ab}}$ & $0.0 \pm 0.0^{\mathrm{b} 0}$ & $100 \%$ \\
A0B3 & $0.0 \pm 0.0^{\mathrm{c}}$ & $22.3 \pm 2.2^{\mathrm{a}}$ & $0.0 \pm 0.0^{\mathrm{b}}$ & $100 \%$ \\
A1B1 & $10.3 \pm 1.0^{\mathrm{a}}$ & $0.0 \pm 0.0^{\mathrm{f}}$ & $0.0 \pm 0.0^{\mathrm{b}}$ & $0 \%$ \\
A1B2 & $0.0 \pm 0.0^{\mathrm{c}}$ & $13.3 \pm 2.2^{\mathrm{bcd}}$ & $1.3 \pm 1.5^{\mathrm{ab}}$ & $91.09 \%$ \\
A1B3 & $0.0 \pm 0.0^{\mathrm{c}}$ & $15.5 \pm 2.4^{\mathrm{abc}}$ & $0.5 \pm 1.0^{\mathrm{b}}$ & $96.87 \%$ \\
A2B1 & $6.5 \pm 2.4^{\mathrm{b}}$ & $0.8 \pm 1.0^{\mathrm{f}}$ & $0.0 \pm 0.0^{\mathrm{b}}$ & $10.95 \%$ \\
A2B2 & $0.0 \pm 0.0^{\mathrm{c}}$ & $12.8 \pm 3.6^{\mathrm{bcd}}$ & $0.0 \pm 0.0^{\mathrm{b}}$ & $100 \%$ \\
A2B3 & $0.0 \pm 0.0^{\mathrm{c}}$ & $13.3 \pm 2.1^{\mathrm{bcd}}$ & $0.3 \pm 0.5^{\mathrm{b}}$ & $97.79 \%$ \\
A3B1 & $9.0 \pm 1.2^{\mathrm{ab}}$ & $0.0 \pm 0.0^{\mathrm{f}}$ & $0.0 \pm 0.0^{\mathrm{b}}$ & $0 \%$ \\
A3B2 & $0.0 \pm 0.0^{\mathrm{c}}$ & $13.5 \pm 2.1^{\mathrm{bcd}}$ & $2.5 \pm 0.6^{\mathrm{ab}}$ & $84.38 \%$ \\
A3B3 & $0.0 \pm 0.0^{\mathrm{c}}$ & $4.5 \pm 4.0^{\text {ef }}$ & $2.3 \pm 3.3^{\mathrm{ab}}$ & $66.18 \%$ \\
A4B1 & $11.5 \pm 3.5^{\mathrm{a}}$ & $0.0 \pm 0.0^{\mathrm{f}}$ & $0.0 \pm 0.0^{\mathrm{b}}$ & $0 \%$ \\
A4B2 & $0.0 \pm 0.0^{\mathrm{c}}$ & $12.3 \pm 3.6^{\mathrm{bcd}}$ & $0.0 \pm 0.0^{\mathrm{b}}$ & $100 \%$ \\
A4B3 & $0.3 \pm 0.5^{\mathrm{c}}$ & $7.0 \pm 7.1^{\text {def }}$ & $4.3 \pm 3.3^{\mathrm{a}}$ & $60.34 \%$ \\
A5B1 & $10.5 \pm 1.7^{\mathrm{a}}$ & $0.0 \pm 0.0^{\mathrm{f}}$ & $0.0 \pm 0.0^{\mathrm{b}}$ & $0 \%$ \\
A5B2 & $0.0 \pm 0.0^{\mathrm{c}}$ & $11.8 \pm 3.1^{\mathrm{bcde}}$ & $0.0 \pm 0.0^{\mathrm{b}}$ & $100 \%$ \\
A5B3 & $0.5 \pm 0.6^{\mathrm{c}}$ & $9.5 \pm 3.7^{\mathrm{cde}}$ & $2.5 \pm 2.6^{\mathrm{ab}}$ & $76 \%$
\end{tabular}

$A(0,1,2,3,4,5)=$ banana stem extract concentration $(0 \%, 1 \%, 2 \%, 4 \%, 8 \%$ and sulfaquinoxalline); $B(1,2,3)=$ incubation period (1, 2 and 3 days). Values bearing the same superscript within columns were not significantly different at 5\% HSD. 
As antimicrobial, it is speculated that the mechanism which may affect Eimeria stiedai oocysts like in bacteria is that the agent would prevent the formation or transportation of each component to the cell wall, resulting in the weakening structure followed by discarding cell wall and discharging cell content that eventually mortified or inhibited the growth of bacteria cell (Prasetyo et al., 2010).

\section{Conclusions}

This research conformed the therapeutic potential of banana stem extract as an alternative coccidiostat on rabbit coccidiosis, moreover the mechanism of banana stem extract as an antibacterial requires further study.

\section{Acknowledgement}

The project was supported by Institutional Research of Jenderal Soedirman University. The author would like to thank all of the persons and institutions which involved in this research, especially to the Animal Health Laboratory, Faculty of Animal Husbandry, University of Jenderal Soedirman, Purwokerto, Central Java, Indonesia.

\section{References}

Al-Fifi ZIA. 2007. Effect of leaves extract of Carica papaya, Vernonia amigdalina and Azadiractcha indica on the coccidiosis in free-range chickens. Asian J. Animal Sci. 1(1):26-32.

Al-Mathal EM. 2008. Hepatic Coccidiosis of the Domestic Rabbit Oryctolagus cuniculus domesticus L. in Saudi Arabia. World Journal of Zoology. 3 (1):30-35.

Al-Rukibat RK, AR Irizarry, JK Lacey, KR Kazacos, ST Storandt and DB DeNicola. 2001. Impression smear of liver tissue from a rabbit. Vet. Clin. Pathol. 30:57-61.

Chapman HD and Jeffers TK. 2014. Vaccination of chicken against coccidiosis ameliorates drug resistance in commercial poultry production. International Journal for Parasitology. 4(2014): 214-217.

Coudert P, D Licois, F Drouet-Viard. 1995. Eimeria species and strain of rabbits. In: Eckert J, Braun R, Shirley MW, Coudert P., editor. Biotechnology, Guidelines on Techniques in Coccidiosis
Research. Brussels, Luxembourg: ECSC-EC-EAEC. 52-73.

Drăgan L, A Györke, JFS Ferreira, IA Pop, I Dunca, M Drăgan, V Mircean, I Dan and V Cozma. 2014. Effects of Artemisia annua and Foeniculum vulgare on chickens highly infected with Eimeria tenella (Phylum Apicomplexa). Acta Veterinaria Scandinavica. 56:22.

lordanche F, M lonita, LI Mitrea, C Fafaneata, and A Pop. 2015. Antimicrobial and antiparasitic activity of lectins. Current Pharmaceutical Biotechnology. 16(2):1-10.

Islam KR, T Farjana, N Begum and MMM Mondal. 2008. In vitro efficacy of some indegenous plants on the inhibition of development of eggs of Ascaridia galli (digenia: nematoda). Bangl. J. Vet. Med. 6(2):159-167.

Iqbal A, KA Tariq, VS Wazir and R Singh. 2013. Antiparasitic efficacy of Artemisia absinthium, toltrazuril and amprolium against intestinal coccidisosis in goats. J. Parasit. Dis. 37(1):88-93.

Kant V, P Singh, PK Verma, I Bais, MS Parmar, A Gopal and V Gupta. 2013. Anticoccidial drugs used in the poultry: an overview. Science International. 261-265.

Matekaire T, JF Mupangwa and EF Kanyamura. 2005. The efficacy of banana plant (Musa paradisiaca) as a coccidiostat in rabbits. Intern. J. Appl. Res. Vet. Med. 3 (4):326-331.

Molan AL, Z Liu and S De. 2009. Effect of pine bark (Pinus radiata) extracts on sporulation of coccidian oocysts. Folia Parasitologica. 56(1):1-5.

Nelson SC, RC Ploetz and AK Kepler. 2006. Musa species (bananas and plaintains). Hawai. USA: Permanent Agriculture Resources (PAR). 1-32.

Ningsih AP, Nurmiati, and A Agustien. 2013. Antibacterial Activity of Crude Extracts of Kepok Kuning Banana (Musa paradisiaca Linn.) against Staphylococcus aureus and Escherichia coli. J. Bio. UA. 2(3): 207-213 (article in Indonesian with an English abstract).

Pakandl M. Coccidia of rabbit: a review. Folia Parasitologica 2009; 56(3):153-166.

Prasetyo BF, I Wientarsih, and BP Priyosoeryanto. 2010. Activity of Ambon banana extract in gel formulation on the wound healing process of mice skin. Jurnal Veteriner. 11(2):70-73 (article in Indonesian with an English abstract).

Price KR. 2012. Use of live vaccines for coccidiosis control in replacement layer pullets. JAPR: Review. 679-692.

Steel RGD and JH Torrie. 1980. Principles and Procedures of Statistics. McGraw-Hill Inc.

Venkatesh, V Krishna, KK Girish, K Pradeepa, and KSR Santosh. 2013. Antibacterial activity of ethanol extract of Musa paradisiaca cv. puttabale and 
Musa acuminate cv. grand naine. Asian J. Pharm. Clin. Res. 6:169-172.

Wall MM. 2006. Ascorbic acid, vitamin A and mineral composition of banana (Musa sp.) and papaya (Carica papaya) cultivars grown in Hawaii. Journal of Food Composition and Analysis. 19:434-445.

Williams RB. 2002. Anticoccidial vaccines for broiler chickens: pathways to success. Avian Pathology. 31:317-353.

Wina E. 2001. Banana plant as ruminant feed. Wartazoa. 11(1):20-27 (article in Indonesian with an English abstract).

Wina ED, Yulistiani, S Kompiang, IW Mathius, W Puastuti, S Askar and Gunawan. 2000. Identifikasi senyawa sekunder dan mineral pada batang pisang. Research Report No Protocol: HP/Nut-T01/APBN 1999/2000. Balitnak, Bogor.
Yang JF, RQ Wang, RQ Lv, DH Zhou, G Duan and FC Zou. 2012. Anticoccidial Activity of Eupatorium adenophorum exstracts againts chicken coccidian oocysts. J. Anim. Vet. Adv. 11(8):1255-1257.

Yellita Y, U Cahyaningsih, DI Pradono, W Winarsih and W Manalu. 2011. Extracts of Andrographis paniculata decreased pathogenicity of oocyst Eimeria tenella. Jurnal Veteriner. 12(4): 307-318 (article in Indonesian with an English abstract).

Yon HJ and JW Noh. 2001. Screening of the anticoccidial effects of herb extracts against Eimeria tenella. Vet. Parasitol. 96:257-258.

Zaman MA, Z Iqbal, RZ Abbas, and mS Ehtisham-ulHaque. 2015. In vitro efficacy of herbal extracts against Eimeria tenella. Int. J. Agric. Biol. 17:848850. 